\title{
Effects of Mepiquat Chloride and Trinexapac-Ethyl on Oil Composition, Seed Yield and Endogenous Gibberellins in Flax
}

\author{
Sang Kuk Kim, Hee Dong Lee ${ }^{1}$ and Hong Jib Choi* \\ Division of Crop Science, Gyeongsangbuk-do Agricultural Research \& Extension Services, Daegu 702-708, Korea \\ ${ }^{1}$ National Institute of Agricultural Science and Technology, RDA, Suwon 441-707, Korea
}

\begin{abstract}
The aim of this field experiment was to investigate the possible effects of mepiquat chloride (TE) and trinexapac-ethyl (MC) on oil composition, seed yield and endogenous gibberellins content of flax cultivar. Foliar application of plant growth retardants mepiquat chloride $\left(0.897,1.794\right.$ and $2.691 \mathrm{~kg}$ a.i. ha $\left.{ }^{-1}\right)$ and trinexapac-ethyl $(0.756$, 1.512 and $2.668 \mathrm{~kg}$ a.i. ha ${ }^{-1}$ ) had significantly increased seeds ripening rate and seed yield. In contrast, plant height was decreased by foliar application of MC and TE. The application of MC significantly increased seed oil yield ( $730 \mathrm{~kg} \mathrm{ha}^{-1}$ by $27.0 \%$ ) compared to the control. Seed and oil yield, and unsaturated fatty acids (oleic acid, linoleic acid and linolenic acid) were increased by foliar application of MC.
\end{abstract}

Key words - Flax, Mepiquat chloride, Trinexapac-ethyl, Oil, Fatty acid, Gibberellins

\section{Introduction}

Flax seeds, which are mainly used for oils are an annual crop belonging to the family Linaceae (Simmonda, 1976). It is grown worldwide either for the oil extracted from the seed or for fiber from the stem. The meal that remains after oil is extracted from the seed is fed to animals as a protein supplement (Lennerts, 1983). Flaxseed is composed of 35 to $40 \%$ protein and together with cottonseed and sunflower supplies about $23 \%$ of the world's oilcake and meal (Hatje, 1989). Furthermore, flax is also an economically important oilseed crop, especially in Canada, that produces about 40\% of the world's flaxseed (Oomah and Mazza, 1999). Plant growth regulators, particularly growth retardants can enhance crop productivity by modifying internal hormonal balance and improving sink-source relationships (Singh et al., 1987). Mepiquat chloride as one of gibberellins biosynthetic inhibitors has been found to restrict the vegetative growth in the cost of enhanced reproductive organs (Wang et al., 1995). Fan et al. (1999) reported that mepiquat chloride improved photosynthetic efficiency. In addition, the good population type and canopy structure for dwarf plants, smaller leaves and bigger bolls

*Corresponding author. E-mail : chj1217@korea.kr could be achieved by mepiquat chloride application. Mepiquat chloride and trinexapac-ethyl tend to be shorter and more compact than untreated plants (Jung et al., 1975; Willard et al., 1976; Stuart et al., 1984, Kerby 1985; Hodges et al., 1991; Reddy et al., 1992). Hence, we proposed these studies with the objective to demonstrate the effect of MC and TE on oil composition, seed yield, endogenous gibberellins content in flax plant.

\section{Materials and Methods}

Field experiment was conducted at the Institute for Bioresources Research, Gyeongbuk Province Agricultural Technology Administration, Andong, Repubic of Korea. Flax seeds were planted in $4.8 \mathrm{~m}$ (16 rows) with $6.0 \mathrm{~m}$ (row length) plots covered with black polyethylene vinyl on March 9 2010. Row spacing (wide) was $0.3 \mathrm{~m}$ and plant density was $11,111 \mathrm{ha}^{-1}$. Prior to seeding, fertilizer was supplied with nitrogen, phosphorus, and potassium at the 100,25 , and $90 \mathrm{~kg}$ $\mathrm{ha}^{-1}$, incorporating as basal and top dressing $(7: 3, \mathrm{w} / \mathrm{w})$ to the soil, respectively.

The experiment featured seven treatments: untreated control, mepiquat chloride (MC) $0.897 \mathrm{~kg}$ a.i. ha ${ }^{-1}(200 \mathrm{ppm}), 1.794 \mathrm{~kg}$ a.i. $\mathrm{ha}^{-1}(400 \mathrm{ppm}), 2.691 \mathrm{~kg}$ a.i. $\mathrm{ha}^{-1}(600 \mathrm{ppm})$, trinexapac- 
ethyl (TE) $0.756 \mathrm{~kg}$ a.i. $\mathrm{ha}^{-1}(100 \mathrm{ppm}), 1.512 \mathrm{~kg}$ a.i. ha ${ }^{-1}(200$ ppm), and $2.668 \mathrm{~kg}$ a.i. $\mathrm{ha}^{-1}(300 \mathrm{ppm})$. MC and TE were foliar-sprayed at 50 days after seeding. The each solution volume applied was also $930 \mathrm{~L} \mathrm{ha}^{-1}$. The untreated check was sprayed with distilled water. All foliar spray was done early hours of the day to reduce evaporation in the morning. A randomized complete block design with four replications was used. Flax seeds were harvested from 22 July to 10 August 2009 depending on seed ripening degree.

Oil content and fatty acid composition were determined from matured flax seed. Crushed flax seed ( $5 \mathrm{~g}$ fresh weight) was extracted by percolating with diethyl ether $100 \mathrm{ml}$ using soxhlet apparatus. For analysis of fatty acid, the extracted solvent derived from soxhlet was evaporated and concentrated. Fatty acid methyl esters were prepared from in $200 \mathrm{~mL}$ of a $1 \%(\mathrm{w} / \mathrm{v})$ solution of sodium methoxide in methanol as described previously (Hitz et al., 1994). After 20 min of incubation at room temperature, fatty acid methyl esters were recovered by the addition of $250 \mathrm{ml}$ of $1 \mathrm{M}$ sodium chloride and extraction with $250 \mathrm{ml}$ of heptane and analyzed using a gas chromatogram (Model HP 5890, USA). Fatty acid methyl esters were resolved using an Omegawax 320 column (Supelco, PA, USA), and the oven temperature was programmed from $185^{\circ} \mathrm{C}$ to $215^{\circ} \mathrm{C}$ at a rate of $2.5^{\circ} \mathrm{C} / \mathrm{min}$.

Extraction and analysis of gibberellin metabolites followed the reference (Lee et al., 1998). The seeds harvested were immediately frozen in liquid nitrogen and stored at $-80^{\circ} \mathrm{C}$. When all the required materials for GA analysis had been collected, the samples were lyophilized for $48 \mathrm{~h}$. The extraction of endogenous gibberellins was followed as described by Lee et al. (1998). The GAs were chromatographed on a $3.9 \times 300 \mathrm{~mm} \mu$ BondaPak $\mathrm{C}_{18}$ column (Waters) and eluted at $1.5 \mathrm{ml} \mathrm{min}{ }^{-1}$ with following gradient: 0 to $5 \mathrm{~min}$, isocratic $28 \% \mathrm{MeOH}$ in $1 \%$ aqueous acetic acid; 5 to $35 \mathrm{~min}$, linear gradient from 28 to $86 \% \mathrm{MeOH} ; 35$ to $36 \mathrm{~min}, 86$ to $100 \%$ $\mathrm{MeOH} ; 36$ to $40 \mathrm{~min}$, isocratic $100 \% \mathrm{MeOH}$. Up to 50 fractions of $1.5 \mathrm{ml}$ each were collected. Small aliquots $(15 \mu \mathrm{l})$ from each fraction were taken, and radioactivity was measured with liquid scintillation spectrometry (Beckman, LS 1801) to determine accurate retention times of each GA based upon the elution of $3 \mathrm{H}-\mathrm{GA}$ standards. The fractions were dried on a Savant Speedvac and combined according to the retention times of 3H-GA standards and previously determined retention times of the labeled (deuterated) GA standards.

GAs were quantified using [17, 17-2H2]-GAs (20 ng each) as internal standards (purchased from Prof. L. N. Mander, Australian National University, Canberra, Australia). The five prominent ions were analyzed by GC-MS-SIM (Finnigan Mat GCQ) with dwell times of $100 \mathrm{~ms}$. The endogenous GA contents were calculated from the peak area ratios respectively. Retention time was determined by the hydrocarbon standards to calculate the KRI value.

The collected data for endogenous gibberellins and tuber yield were analyzed by using SAS package for Duncan's multiple range tests.

\section{Results and Discussion}

In the present study, growth characteristics such as plant height, number of branch, capsule per plant, and seed yield in flax plants were first elucidated with gibberellin biosynthetic inhibitors, MC and TE. It is known that mepiquat chloride is a plant growth regulator which suppresses vegetative growth in cotton (York, 1983b). The difference between the high concentration and low concentration in both MC and TE also showed significant (Table 1). MC and TE significantly decreased plant height as compared to the control. TE is one of the newest growth regulators in agriculture and horticulture. It acts by inhibiting gibberellins biosynthesis resulting in shorter internode length and it inhibits gibberellin production much later in the biosynthetic pathway than $\mathrm{MC}$, chloromequat, and triazole compounds (Rademacher, 2000; Hafner, 2001). Qian (1998) reported that TE reduced stem elongation and mowing requirements stimulating a favorable vertical shoot growth in turfgrass. Plant height was reduced by 3.6 to $10.6 \%$, and reductions in plant height were closely correlated with final height of the untreated flax. Mepiquat chloride slightly increased 1,000 -seed weight by 6.6 to $8.6 \%$. Seed yield was increased by 11.0 to $21.6 \%$ and by 7.9 to $11.8 \%$ in $\mathrm{MC}$ and $\mathrm{TE}$ as a result of the increased seed weight. MC and TE applications produced a statistically significant difference in decreased plant height which is contributed to minimizing lodging as compared to the control. MC regulating plant growth has been extensively researched and well documented 
in cotton (York, 1983a; 1983b). It was reported that MC tends to be shorter and more compact than untreated plants (Jung et al., 1975; Willard et al., 1976; Stuart et al., 1984; Kerby, 1985; Hodges et al., 1991; Reddy et al., 1992). Number of branch per plant in the MC and TE was increased by high concentration, which is attributed to the significant increase in seed yield. Number of branch per plant was apparently affected by both MC and TE treatments depending on the differently applied concentrations. Increased branches were observed at highest (300 ppm) and medium (200 ppm) concentrations by TE treatment, whilst MC treatment resulted in an increased branch at the highest concentration (600 ppm). The significantly increased number of branch per plant was observed in TE at $300 \mathrm{ppm}$. It suggested that the increased seed yield was associated with increased number of branch per plant and high ripened seed rate. The increased branch and capsule per plant as well as the ripened seed rate on flax plant were promoted by two gibberellins biosynthetic inhibitors MC and TE (Table 1). The occurrence of side branch per plant was significantly increased by the both $\mathrm{MC}$ and TE treatment. Among various levels of $\mathrm{MC}$ treatment, $600 \mathrm{ppm}$ exhibited maximum occurrence of side branches of flax plant compared to the control and TE treatment. Foliar spray of 300 ppm with TE leaded to increase the occurrence of side branches per plant. Number of capsule per plant was also increased by MC and TE treatments ranging 17.5 to 21.5 as compared to the control. The number of capsule per plant in MC 600 ppm application was more increased than that of TE. The highest amounts of capsules were produced with TE treatment at 300 ppm. TE treatment in ability forming capsules was more stimulated than that of MC.

Both MC and TE applications increased the ripened seed rate at a wide range of concentration. In these treatments, seed-ripened rate was more increased in TE treatment than in MC application. All concentrations in MC gave significant higher seed yield comparing to the yield obtained from the control. Seed yield was obtained following MC 200 ppm, MC 400 ppm and MC 600 ppm application. The increased seed yield among these treatments reached almost $10.9 \%$, $11.5 \%$, and $12.2 \%$, respectively. The differences between the effects of $\mathrm{MC}$ and $\mathrm{TE}$ in the seed ripening rate showed statistically significant, however, the differences between applied concentration in each growth retardant were statistically insignificant.

Table 1. Effect of MC and TE on growth characteristics and seed yield of flax cv. Hwanam.

\begin{tabular}{lccccccc}
\hline \hline Treatments & $\begin{array}{c}\text { Conc. } \\
(\mathrm{ppm})\end{array}$ & $\begin{array}{c}\text { Plant height } \\
(\mathrm{cm})\end{array}$ & $\begin{array}{c}\text { No. of branch per } \\
\text { plant }\end{array}$ & $\begin{array}{c}\text { No. of capsule } \\
\text { per plant }\end{array}$ & $\begin{array}{c}\text { Ripened seed rate } \\
(\%)\end{array}$ & $\begin{array}{c}1,000 \text {-seed weight } \\
(\mathrm{g})\end{array}$ & $\begin{array}{c}\text { Seed yield } \\
(\mathrm{kg} / \mathrm{ha})\end{array}$ \\
\hline Control & & $85.6 \mathrm{a}$ & $6.4 \mathrm{~b}$ & $17.1 \mathrm{c}$ & $88.6 \mathrm{c}$ & $5.91 \mathrm{~b}$ & $1,614 \mathrm{~d}$ \\
$\mathrm{MC}$ & 200 & $81.4 \mathrm{c}$ & $6.6 \mathrm{~b}$ & $18.9 \mathrm{~b}$ & $93.7 \mathrm{a}$ & $6.30 \mathrm{~b}$ & $1,791 \mathrm{~b}$ \\
& 400 & $79.3 \mathrm{c}$ & $7.9 \mathrm{a}$ & $20.2 \mathrm{a}$ & $93.5 \mathrm{a}$ & $6.31 \mathrm{~b}$ & $1,859 \mathrm{~b}$ \\
& 600 & $76.5 \mathrm{~d}$ & $8.5 \mathrm{a}$ & $21.5 \mathrm{a}$ & $94.1 \mathrm{a}$ & $6.42 \mathrm{a}$ & $1,963 \mathrm{a}$ \\
\hline TE & 100 & $82.1 \mathrm{~b}$ & $6.5 \mathrm{~b}$ & $17.2 \mathrm{c}$ & $90.2 \mathrm{~b}$ & $5.93 \mathrm{~b}$ & $1,742 \mathrm{c}$ \\
& 200 & $82.5 \mathrm{~b}$ & $6.8 \mathrm{~b}$ & $17.5 \mathrm{c}$ & $91.2 \mathrm{~b}$ & $6.31 \mathrm{~b}$ & $1,755 \mathrm{c}$ \\
& 300 & $80.3 \mathrm{c}$ & $8.1 \mathrm{a}$ & $18.7 \mathrm{~b}$ & $91.9 \mathrm{~b}$ & $6.32 \mathrm{~b}$ & $1,804 \mathrm{~b}$ \\
\hline
\end{tabular}

Table 2. Effect of MC and TE on oil content and fatty acid composition of flax cv. Hwanam.

\begin{tabular}{|c|c|c|c|c|c|c|c|c|c|}
\hline \multirow{2}{*}{ Treatments } & \multirow{2}{*}{$\begin{array}{l}\text { Conc. } \\
\text { (ppm) }\end{array}$} & \multirow{2}{*}{$\begin{array}{l}\text { Oil content } \\
\text { (g/kg FW) }\end{array}$} & \multirow{2}{*}{ Iodine index } & \multirow{2}{*}{$\begin{array}{c}\text { Ratio of } \\
\text { SFA:USFA }\end{array}$} & \multicolumn{5}{|c|}{ Fatty acid composition (\%) } \\
\hline & & & & & Palmitic & Stearic & Oleic & Linoleic & Linolenic \\
\hline Control & & $356 \mathrm{c}$ & $155 b$ & $10.1 \mathrm{e}$ & $5.2 \mathrm{a}$ & $3.6 \mathrm{a}$ & $17.7 d$ & $16.0 \mathrm{c}$ & $55.5 \mathrm{c}$ \\
\hline \multirow[t]{3}{*}{$\mathrm{MC}$} & 200 & $353 \mathrm{c}$ & $159 \mathrm{ab}$ & $11.0 \mathrm{~d}$ & $5.0 \mathrm{a}$ & $3.2 b$ & $18.7 \mathrm{c}$ & $16.4 \mathrm{c}$ & $55.6 \mathrm{c}$ \\
\hline & 400 & $359 \mathrm{~b}$ & $162 \mathrm{a}$ & $12.5 \mathrm{c}$ & $4.6 \mathrm{~b}$ & $2.8 \mathrm{c}$ & $19.5 b$ & $17.0 \mathrm{~b}$ & $57.1 \mathrm{~b}$ \\
\hline & 600 & $372 \mathrm{a}$ & $163 \mathrm{a}$ & $13.3 b$ & $4.6 b$ & $2.9 \mathrm{c}$ & $20.5 \mathrm{a}$ & $18.6 \mathrm{a}$ & $61.3 \mathrm{a}$ \\
\hline \multirow[t]{3}{*}{$\mathrm{TE}$} & 100 & $359 b$ & $159 \mathrm{ab}$ & $10.9 \mathrm{~d}$ & $5.2 \mathrm{a}$ & $3.3 \mathrm{bc}$ & $9.1 \mathrm{bc}$ & $17.0 \mathrm{~b}$ & $56.5 \mathrm{bc}$ \\
\hline & 200 & $357 \mathrm{c}$ & $161 \mathrm{a}$ & $12.5 \mathrm{c}$ & $4.7 b$ & $3.0 \mathrm{c}$ & $19.7 \mathrm{a}$ & $18.4 \mathrm{a}$ & $59.1 \mathrm{a}$ \\
\hline & 300 & $361 b$ & $163 a$ & $14.4 \mathrm{a}$ & $4.2 b$ & $2.5 \mathrm{~d}$ & $20.3 \mathrm{a}$ & $18.4 \mathrm{a}$ & $57.6 \mathrm{~b}$ \\
\hline
\end{tabular}


TE treatment showed slightly an increase in ripened seed rate although it was low compared to the MC treatment. The 1,000 -grain weight in flax seed between treatments ranged 6.30 to $6.42 \mathrm{~g}$. MC treatment exhibited more increased seed weight than that of TE. The highest seed weight was only observed at $600 \mathrm{ppm} \mathrm{MC}$ treatment. MC treatment produced seed yield 10.9 to $21.6 \%$ and TE treatment also increased 7.9 to $11.8 \%$ compared to the control. The TE-treated flax had fewer seed yield and 1,000-seed weight than that of the MC-treated flax. The significant increase of seed yield in MC treatment was observed $600 \mathrm{ppm}$ between these concentrations. The highest increase in seed yield was found with $\mathrm{MC}$, followed by TE. Foliar spray of MC 600 ppm showed a significant increase in seed yield (by about 21.6\%) as compared with control, MC 200 and 400 ppm.

The oil content, iodine index, ratio of SFA (saturated fatty acid) for USFA (unsaturated fatty acid) and fatty acid composition was determined from flax seed as affected by two gibberellins biosynthetic inhibitors (Table 2). Oil content in MC and TE treatment was ranged by 35.3 to $37.2 \mathrm{~g} \mathrm{~kg}^{-1}$. Oil contents between these treatments were higher than that of control except for MC 200 ppm treatment. Foliar spray of $600 \mathrm{ppm}$ in MC treatment induced the highest oil content. Application of the MC in flax oil contents made up 35.3 to $37.22 \mathrm{~g} \mathrm{~kg}^{-1}$ depending on rates of applied MC concentration. The highest oil content was obtained when introducing 600 ppm of MC in vegetative stage. The seed oil content tended to decrease when low MC and TE rate was applied but tended to increase with the application of MC and TE.

Farooqi and Sharma (1988) reported that plant growth retardant such as chlormequat chloride increased significantly oil contents and inhibited growth in Japanese mint.

Iodine index treated with $\mathrm{MC}$ and TE ranged from 159 to 163. The ratio of SFA for USFA was also ranged 10.9 to 14.4. The ratio of SFA against USFA in both MC and TE treatments was significantly increased with an elevated concentration. High ratio of SFA against USFA in both MC and TE treatment was observed at highest concentration. The ratio of SFA against USFA in TE treatment was 14.4 at 300 ppm. In fatty acid compositions, saturated fatty acids such as palmitic acid and stearic acid were slightly decreased by MC and TE treatment. Unsaturated fatty acid of flax seed was occupied by $91.0 \%$ and among these fatty acid compositions, linolenic acid showed highest as $56.6 \%$. Meanwhile saturated fatty acid was relatively low as $9.0 \%$. The TE treatment gave the lowest total saturated fatty acid composition, followed by MC. Unsaturated fatty acids such as oleic acid and linoleic acid were also slightly increased with showing a similar tendency like that of saturated acids. However, the only unsaturated fatty acid, linolenic acid, was decreased showing opposite results to that of oleic acid and linoleic acid. High a-linolenic acid flaxseed is one of the richest dietary sources of a-linolenic acid and is also a good source of soluble fiber mucilage (Cunnane et al., 1993).

Two bioactive gibberellins $\left(\mathrm{GA}_{1}\right.$ and $\left.\mathrm{GA}_{4}\right)$ and total gibberellins in the flax seed as affected by different concentration in $\mathrm{MC}$ and TE are shown in Fig. 1. In a previous report, we have shown that eight endogenous gibberellins were identified and
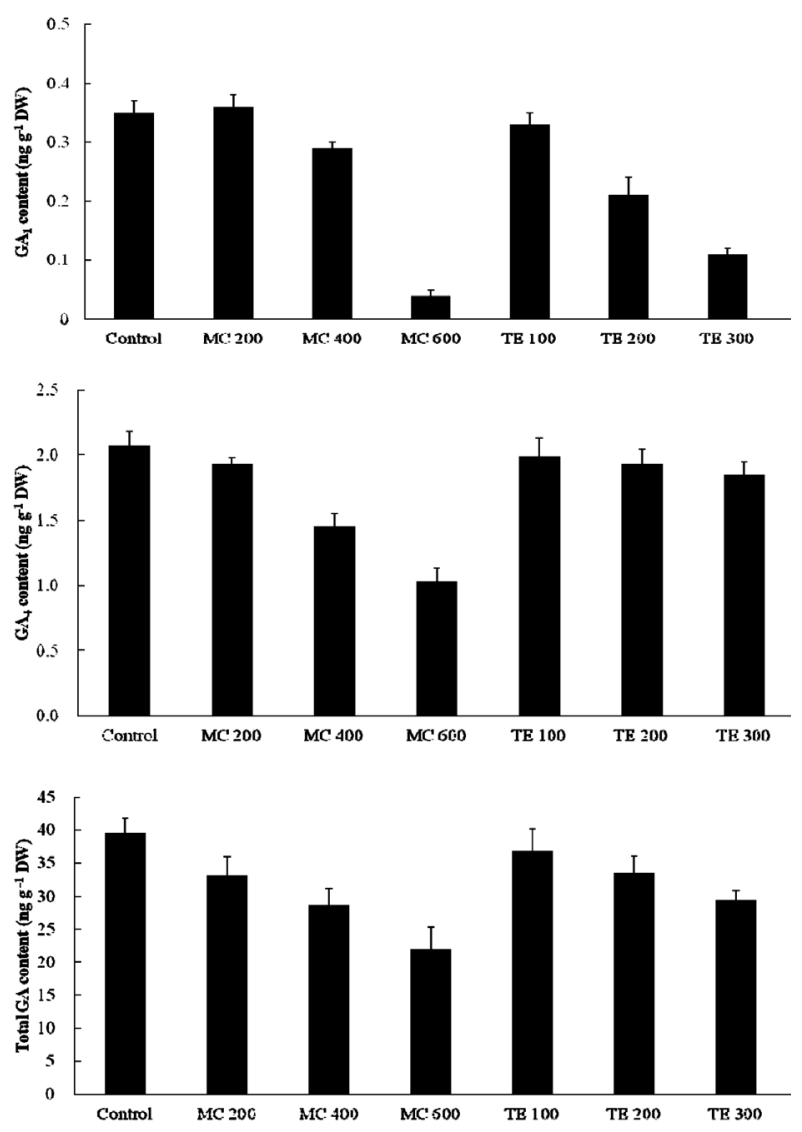

Fig. 1. Changes of active and total gibberellins content as affected by MC and TE in flax cv. Hwanam. Vertical bars indicate SE $(n=3)$. 
the non-C13 hydroxylation pathway was also dominantly operated during seed development in flax plant (Kim et al., 2009). The endogenous $\mathrm{GA}_{1}$ content analyzed from flax seed was slightly decreased at commonly lowest concentration in $\mathrm{MC}$ and TE. Otherwise, the medium (MC 400 ppm and TE $200 \mathrm{ppm}$ ) and highest concentration (MC $600 \mathrm{ppm}$ and TE $300 \mathrm{ppm}$ ) induced the decreased endogenous $\mathrm{GA}_{1}$ content in flax seed. The remarkable decrease in $\mathrm{GA}_{1}$ content was observed at MC $600 \mathrm{ppm}$. In the change of endogenous $\mathrm{GA}_{4}$ content, MC treatment caused a sharp reduction at MC 600 ppm followed by MC 400 ppm. However, TE treatment did not affect endogenous decrease in $\mathrm{GA}_{4}$ content showing a similar content like that of the control. Most plant growth retardants inhibit the formation of growth-active gibberellins and can, thus, be used to reduce unwanted shoot elongation. To date, three different types of chemicals with such an effect have become known: Quaternary ammonium compounds (chlormequat chloride and mepiquat chloride) inhibit the conversion of geranylgeranyl-pyrophosphate to ent-kaurene. The following steps leading to ent-kaurenoic acid are catalyzed by monooxygenases. Compounds with an $N$-containing heterocycle (e.g. anycmidol, flurprimidol, paclobutrazol and uniconazole) inhibit these enzymes (Hedden and Kamiya, 1997). Later stages of GA metabolism involve dioxygenases which require 2-oxoglutarate as a co-substrate. Acylcylcohexanediones, such as trinexapac-ethyl or prohexadione- $\mathrm{Ca}$, are structural mimics of 2-oxoglutarate and can, thus, block these reactions. This may affect positively or negatively the usefulness of a given compound in a distinct indication. Total gibberellin content including two groups which consist of eight gibberellins was also measured from the flax seed as affected by $\mathrm{MC}$ and TE treatment. Total gibberellin content was also reduced in flax seed applied with both MC and TE. Total endogenous gibberellin content was more decreased in $\mathrm{MC}$ treatment than in that of TE treatment. In particular, sharp decrease in total gibberellins was observed in MC 600 ppm treatment. The current study has confirmed that the application of MC and TE increases the seed ripening rate, number of branch, and capsule per plant when applied at vegetative growth.

\section{Literature Cited}

Beall, F. D., P.W. Morgan, L. N. Mander, F.R. Miller and K.H. Babb. 1991. Genetic regulation of development in Sorghum bicolor. Plant Physiol. 95:116-125.

Cunnane, S.C, S. Ganguli and C. Menard. 1993. High alinolenic acid flax seed (Linum usitatissimuin): some nutritional properties in humans. British J. Nutrition 69:443-453.

Fan, S., X. Yuzhang and Z. Chaojun. 1999. Effects of nitrogen, phosphorus and potassium on the development of cotton bolls in summer. Acta Gossypii Sinica 11:24-30.

Farooqi, A.H.A. and S. Sharma. 1988. Effect of growth retardants on growth and essential oil content in Japanese mint. Plant Growth Regul. 7:39-46.

Hafner, V. 2001. Moddus-universal product for lodging prevention in cereals. 5th Slovenian Conference on Plant Protection, Catez ob Savi, Slovenia, 6-8 March. 2001. 167-172.

Hatje, G. 1989. World importance of oil crops and their products. In Robbellen, G, R.K. Downey and A. Ashri (eds.), Oil Crops of the World: Their Breeding and Utilization, McGraw-Hill Pub. Co., New York, USA. pp. $1-21$.

Hedden, P. and Y. Kamiya. 1997. Gibberellin biosynthesis : enzymes, genes and their regulation. Annual Review of Plant Physiol. Plant Molecular Biol. 48:431-460.

Hitz, W.D., T.J. Carlson, J.R. Booth, A.J. Kinney, K.L. Stecca and N.S. Yadav. 1994. Cloning of a higher-plant plastid [omega]-6 fatty acid desaturase cDNA and its expression in a Cyanobacterium. Plant Physiol. 105(2):635-641.

Hodges, H.F., V.R. Reddy and K.R. Reddy. 1991. Mepiquat chloride and temperature effects on photosynthesis and respiration of fruiting cotton. Crop Sci. 31:1302-1308.

Jung, J., B. Wurzer and H. Von Amsberg. 1975. Biological activity of new onium compounds in cotton and other crops. p.13. In Sullivan, E.F. (ed.), Meeting of the Plant Growth Regulator Working Group, Longmont Co., Chicago, IL. pp. 27-29.

Khandelwal, S. K., N.K. Gupta and M.P. Sahu. 2002. Effect of plant growth regulators on growth, yield and essential oil production of henna (Lawsonia inermis L.). J. Horticultural Sci. \& Biotech. 77(1):67-72.

Kerby, T.A. 1985. Cotton response to mepiquat chloride. Agronomy J. 77:515-518. 
Kim, S.K., E.Y. Sohn and I.J. Lee. 2009. Quantification of endogenous gibberellins in two flax (Linum usitatissimum L.) cultivars during seed development. J. Crop Sci. Biotech. 12(1):43-46.

Lee, I.J., K.R. Foster and P.W. Morgan. 1998. Photoperiod control of gibberellin levels and flowering in sorghum. Plant Physiol. 116:1003-1011.

Lennerts, L. 1983. Oelschrote, oelkuchen, pflanzliche oele und fette, herkunft, gewinnung, verwendung. Bonn. Verlag Alfred Strothe, Hannover, Germany. 43-45.

Qian, Y.L. 1998. Trinexapac-ethyl restricts shoot growth and improves quality of 'Diamond' zoysiagrass under shade. Hort. Sci. 33(6):1019-1022.

Oomah, B. D. and G. Mazza. 1999. Health benefits of phytochemicals from selected Canadian crops. Trends in Food Sci. Technol. 193-198.

Rademacher, W. 2000. Growth retardants: effects on gibberellins biosynthesis and other metabolic pathways. An. Rev. Plant Physiol. Plant Mol. Biol. 51:501-577.

Reddy, V.R., A. Trent and B. Acock. 1992. Mepiquat chloride and irrigation versus cotton growth and development. Agronomy J. 84:930-933.

Simmonda, N.W. 1976. Evolution of crop plants. Longman Inc., New York, USA. pp.12-19.
Singh, V.P., M. Singh and S.N. Bhardwaj. 1987. Foliage characters in relation to biomass and seed cotton productivity in upland cottons (Gossypium hirsutum L.). Annals Agric. Res. 8:130-134.

Stuart, B.L., V.R. Isbel, C.W. Wendt and J.R. Abernathy. 1984. Modification of cotton water relations and growth with mepiquat chloride. Agronomy J. 76:651-655.

Wang, Z.L., Y.P. Yin and X.Z. Sun. 1995. The effect of DPC ( $N, N$-dimethyl piperidinium chloride) on the ${ }^{14} \mathrm{CO}_{2}$ assimilation and partitioning of ${ }^{14} \mathrm{C}$ assimilates within the cotton plants interplanted in a wheat stand. Photosynthetica 31:197-202.

Willard, J.I., R.H. Kupelian and P.E. Schott. 1977. Effects of 1, 1-imethylpiperidinium chloride (BAS $08300 \mathrm{~W}$ ) on cotton yield and development. In Brown, J. M. (ed.), Proceedings of Beltwide Cotton Production Research Conference, National Cotton Council of America, Memphis, TN.

York, A.C. 1983a. Cotton cultivar response to mepiquat chloride. Agronomy J. 75:663-667.

York, A.C. 1983b. Response of cotton to mepiquat chloride with varying $\mathrm{N}$ rates and plant populations. Agronomy J. 75:667-672.

(Received 8 August 2011; Revised 24 November 2011; Accepted 2 December 2011) 